\title{
8-Nitroguanine, a Potential Biomarker to Evaluate the Risk of Inflammation-Related Carcinogenesis
}

\author{
Ning $\mathrm{Ma}^{1}$, Mariko Murata ${ }^{3}$, \\ Shiho Ohnishi', Raynoo Thanan², \\ Yusuke Hiraku ${ }^{3}$ and Shosuke Kawanishi ${ }^{2}$ \\ ${ }^{1}$ Faculty of Health Science, \\ Suzuka University of Medical Science, Suzuka, Mie, \\ ${ }^{2}$ Faculty of Pharmaceutical Sciences, \\ Suzuka University of Medical Science, Suzuka, Mie, \\ ${ }^{3}$ Department of Environmental and Molecular Medicine, \\ Mie University Graduate School of Medicine, Tsu, Mie,
}

Japan

\section{Introduction}

Recently, chronic inflammation induced by infection has been postulated to be an important risk factor of various cancers (Schetter et al., 2010; Aggarwal \& Sung, 2011; Kamp et al., 2011; Rook \& Dalgleish, 2011; Trinchieri, 2011). Many malignancies arise from areas of infection and inflammation (Balkwill \& Mantovani, 2001; Coussens \& Werb, 2002). Epidemiological and experimental studies have provided evidence showing that chronic infection and inflammation contribute to a substantial part of environmental carcinogenesis (Coussens \& Werb, 2002; IARC, 2003). It has been estimated that chronic inflammation accounts for approximately $25 \%$ of human cancers (Hussain S. P. \& Harris, 2007). International Agency for Research on Cancer (IARC) has estimated that infectious diseases account for approximately $18 \%$ of cancer cases worldwide (IARC, 2003). During inflammation, nitric oxide (NO) and reactive oxygen species (ROS) are generated from inflammatory cells and considered to play the key role in carcinogenes (Hofseth et al., 2003a; Hofseth et al., 2003b; Hussain S. P. et al., 2003; Ohshima et al., 2003). Inducible nitric oxide synthase (iNOS) catalyzes the production of NO particularly during inflammation, leading to generation of various reactive nitrogen species (RNS), such as NOx and peroxynitrite (ONOO-). RNS generated during infection with influenza viruses can mediate the formation of 8nitroguanine, a nitrative lesion of nucleic acids, via ONOO- formation (Maeda H. \& Akaike, 1998; Akaike et al., 2003). 8-Nitroguanine formed in DNA is chemically unstable, and thus can be spontaneously released, resulting in the formation of an apurinic site (Yermilov et al., 1995a). The apurinic site can form a pair with adenine during DNA synthesis, leading to G:C-to-T:A transversions (Kawanishi \& Hiraku, 2006) (Fig. 1). Thus, 8-nitroguanine is a potentially mutagenic DNA lesion, which can participate in initiation and promotion in the 
infection-related carcinogenesis (Loeb \& Preston, 1986; Kawanishi et al., 2006). Our studies have demonstrated that 8-nitroguanine is formed at the sites of carcinogenesis in humans and experimental animals (Ma et al., 2004; Pinlaor et al., 2004b; Ding et al., 2005; Horiike et al., 2005; Ma et al., 2006; Hoki et al., 2007a; Hoki et al., 2007b; Fujita et al., 2008; Ma et al., 2008; Tanaka et al., 2008; Ma et al., 2009; Ma et al., 2010). Moreover, our studies have demonstrated that 8-nitroguanine was formed in Oct3/4-positve stem cells in $S$. haematobium-associated cystitis and cancer tissues. Inflammation by $S$. haematobium infection may increase the number of mutant stem cells, in which iNOS-dependent DNA damage occures via NF- $\mathrm{\kappa B}$ activation leading to tumor development (Ma et al., 2011).

We describe the procedures of these experiments including the 8-nitroguanine antibody produce method, and employed this rabbit anti-8-nitroguanine polyclonal antibody to examine the formation and localization of 8-nitroguanine in patients and animals with inflammation related carcinogenesis by the immunohistochemical method in our laboratory. These protocols provide a detailed description of methodologies successfully used to define the pattern of 8-nitroguanine expression in pathological samples. Visualization of nuclear 8nitroguanine expression aids in assessment of potential sites of nitrative DNA damage within inflammation-related carcinogenesis. On the basis of our results, we propose that 8nitroguanine is a promising biomarker to evaluate the potential risk of inflammationmediated carcinogenesis.

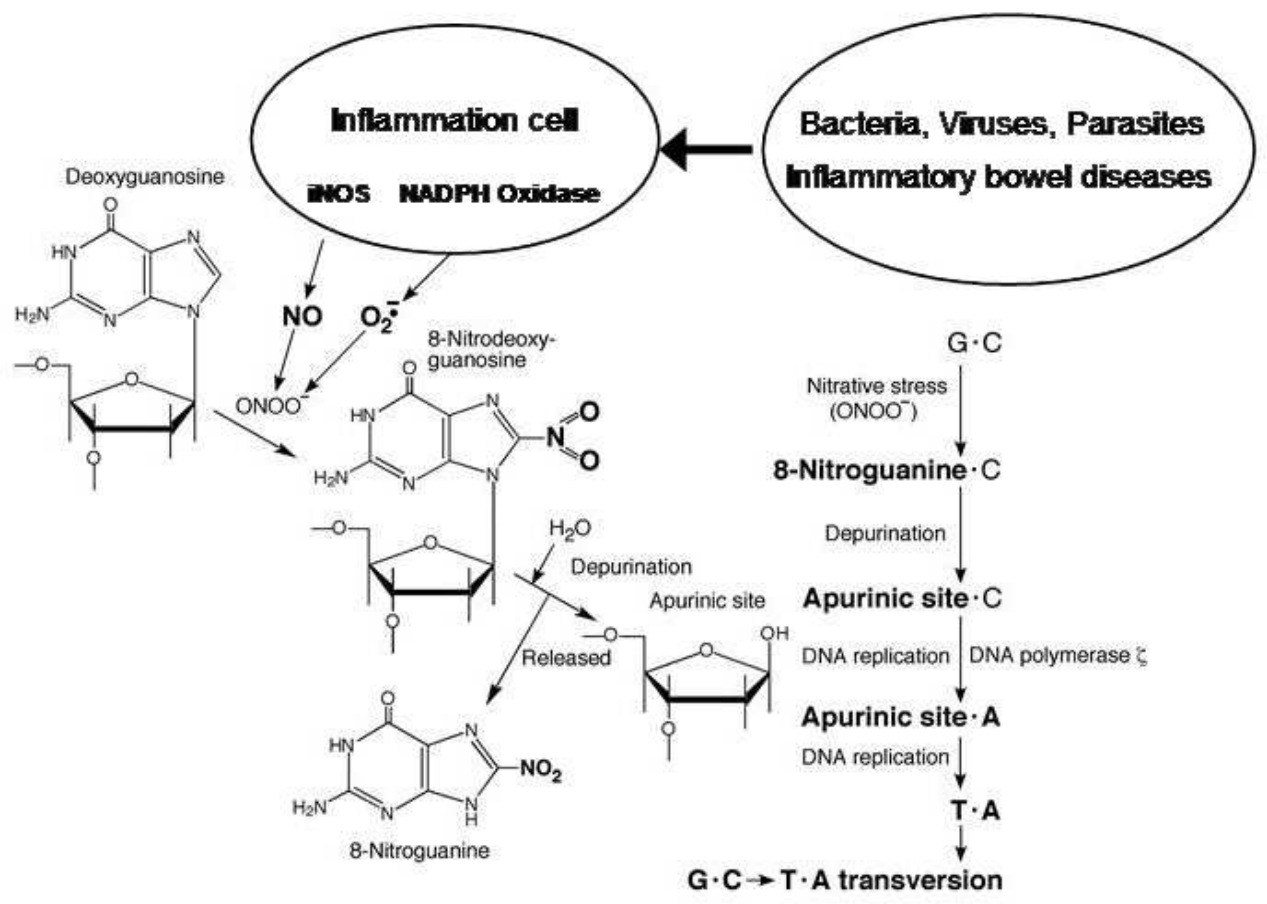

Fig. 1. Formation of 8-nitroguanine during chronic inflammation and proposed mechanism of mutation. 


\section{Immunohistochemical identification of 8-nitroguanine}

\subsection{Production of anti-8-nitroguanine antibody}

Anti-8-nitroguanine polyclonal antibody was produced by a modified method (Akaike et al., 2003). 8-Nitroguanosine was incubated with sodium metaperiodate for $20 \mathrm{~min}$ at room temperature and then conjugated with rabbit serum albumin (RSA) for $1 \mathrm{~h}$ followed by incubation with sodium borohydride for $1 \mathrm{~h}$. The conjugate was dialyzed against $150 \mathrm{mM}$ $\mathrm{NaCl}$ overnight. 8-Nitroguanine-aldehyde-RSA conjugate mixed with Freund's complete adjuvant was injected in rabbit by intracutaneous administration. After 4 weeks of the immunization, the same antigen was given and the blood was taken two weeks later. We immobilized 8-nitroguanine in a cellulofine GCL-2000m column (Seikagaku Kogyo, Tokyo, Japan), and then purified the antibody by affinity chromatography.

\subsection{Specificity of anti-8-nitroguanine antibody}

Specificity of the purified antibody was examined by a dot immunobinding assay and absorption test (Pinlaor et al., 2004a). Purified antibody gave a strong immunostaining only on the spot of 8-nitroguanine conjugate (Fig. 2A). The immunoreactivity disappeared only when the antibody was pre-incubated with 8-nitroguanine. In contrast, immunoreactivity with 8-nitroguanine conjugate did not disappear when the antibody was preincubated with 3-nitrotyrosine, guanosine, 8-oxo-7,8-dihydro-2'-deoxyguanosine (8-oxodG), deoxyguanosine, 8 -bromoguanosine, and xanthosine (Fig. 2B).

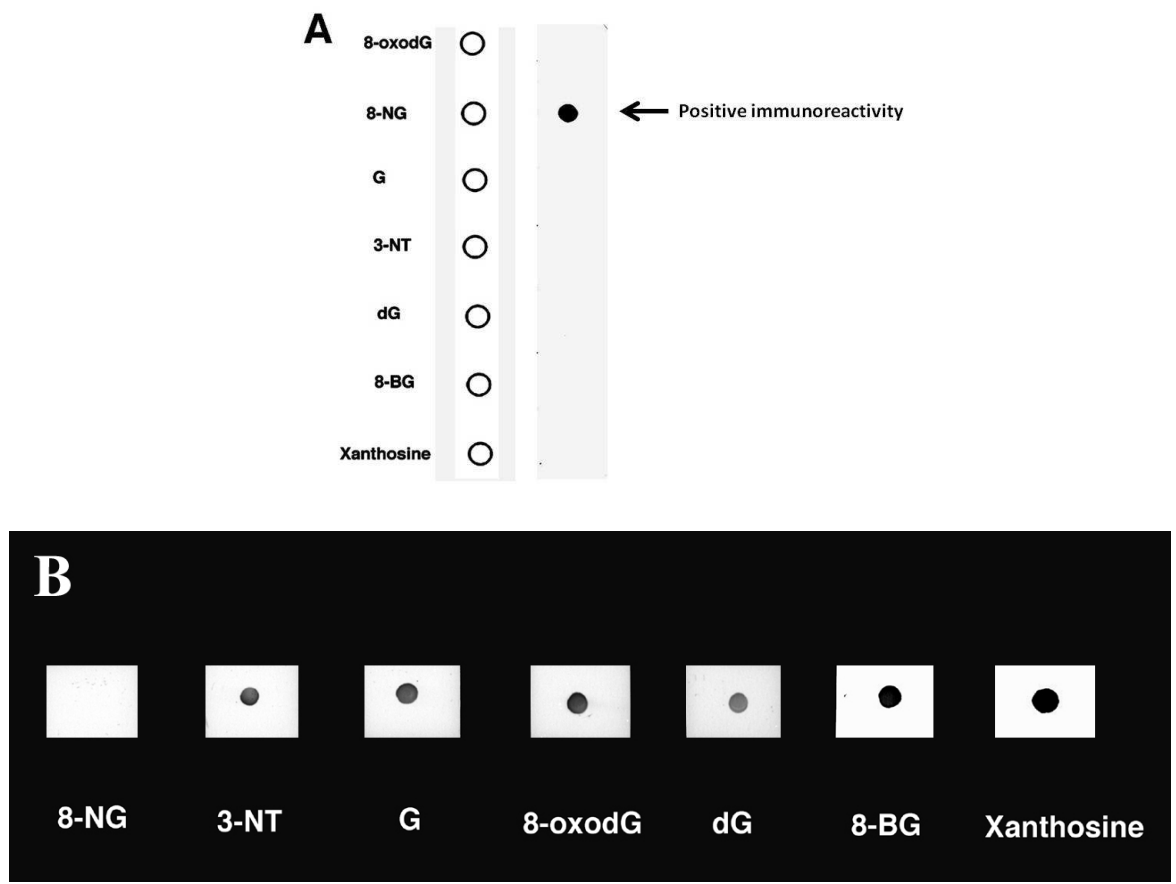

Fig. 2. Dot immunobinding assay and absorption test of anti-8-nitroguanine antibody. 
Antigen-antibody reactions were visualized by the peroxidase-anti-peroxidase method. Purified antibody gave a strong immunostaining only on the spot of 8-nitroguanine conjugate (A). 8-Nitroguanine, 3-nitrotyrosine, guanosine, 8-oxodG and deoxyguanosine were incubated with the antibody at the concentration of $0.7 \mu \mathrm{g} / \mathrm{ml}$, and were applied to 8nitroguanine conjugate. Immunoreactivity disappeared only when the antibody was pretreated with 8-nitroguanine (B). 8-NG, 8-nitroguanine; 3-NT, 3-nitrotyrosine; G, guanosine; $\mathrm{dG}$, deoxyguanosine and 8-BromoG, 8-bromoguanosine.

\subsection{Materials and animals}

\subsubsection{Donor tissue source}

Rat, mouse, hamster, served as the donor tissue source in accordance with the guidelines Proper Care and Use of Laboratory Animals in Research. For the patient's operation samples, written informed consent was obtained from each patient, and the study protocol followed the ethical guidelines of the Declaration of Helsinki.

\subsubsection{Chemicals and reagents for immunohistochemistry (IHC) and special equipment}

Silanized slides (Dako, Japan)

Dapi-Fluoromount-GTM Mounting Medium (Southern Biotech, Birmingham, USA)

Malinol mounting medium (Muto Pure Chemicals Co. Tokyo,Japan)

3,3'-Diaminobenzidine tetrahydrochloride dehydrate (DAB) (Dojindo, Kumamoto, Japan)

Goat anti-rabbit $\gamma$-globulin-HRP (Medical Laboratories, Nagoya, Japan)

Normal goat serum (Medical Laboratories, Nagoya, Japan)

Difco $^{\mathrm{TM}}$ Skim milk (Becton, Dickinson and Company, Sparks, USA)

Rabbit anti-8-nitroguanine antibody (Made by Ma N. et al, Suzuka University of Medical Science, Japan)

Anti-8-hydorxy-2'-deoxyguanosine monoclonal antibody (Japan Institute for the Control of Aging, Shizuoka, Japan)

Rabbit peroxidase-anti-peroxidase (PAP) (ab28054, abcam, Tokyo, Japan)

Alexa 488-labeled goat antibody against mouse IgG (Molecular Probes Inc., Eugene, Oregon, USA)

Alexa 594-labeled goat antibody against rabbit IgG (Molecular Probes Inc., Eugene, Oregon, USA)

Other antibodies from abcam or Santa Cruz Biotechnology, Inc. USA.

Tris-HCl (Sigma, St. Louis, MO, USA)

Sodium chloride (Nacalai, Kyoto, Japan)

Sodium pentobarbital (Nacalai, Kyoto, Japan) 
Ethanol (Nacalai, Kyoto, Japan)

Xylene (Nacalai, Kyoto, Japan)

Paraformaldehyde (Nacalai, Kyoto, Japan)

Monobasic and dibasic salts of sodium and potassium phosphate (Nacalai, Kyoto, Japan)

Confocal laser scanning microscopy (FV-1000D, Olympus, Tokyo, Japan)

Fluorescent light microscope (BX53, Olympus, Tokyo, Japan)

Sliding microtome (RM2265, Leica, Germany)

\subsection{Detailed procedure for IHC}

\subsubsection{Time required for immunohistochemistry of 8-nitroguanine}

Average time for immunohistochemical (IHC) localization of 8-nitroguanine is 2-3 days, not including preparation and mounting of tissues. Albeit, time varies with duration of antibody incubation of second antibody in double fluorescent immunohistochemistry.

\subsubsection{Preparation of animal tissues for IHC}

1. Animal is weighed and anesthetized by intraperitoneal injection of $50 \mathrm{mg} / \mathrm{kg}$ sodium pentobarbital.

2. After the animal has fallen asleep, firmly pinch the foot with a pair of tweezers. If there is no response, then proceed with the surgery.

3. Position the animal on its back. Open the abdominal cavity with a midline incision to the sternum. Make a diagonal cut to each side of the sternum through the rib cage extending to either side of the neck. Care should be taken not to sever any vessels or puncture the heart. The sternum may now be clamped back with hemostatic forceps to give access to the heart.

4. Cut the connective tissue surrounding the diaphragm and make a lateral cut on each side of the animal to allow proper drainage of perfusate.

5. Lift the lungs to expose the descending aorta and occlude the vessel using hemostatic forceps.

6. Make a small incision in the right atrium.

7. Insert an i.v. catheter into the left ventricle. Remove the needle from the catheter. Position so that the tip of the catheter resides within the aortic arch. The optimal size of the catheter for transcardial perfusion is 18 and 22 gauge for rat and mouse, respectively.

8. Connect the catheter to the perfusion apparatus and begin the flow of $0.9 \% \mathrm{NaCl}$ into the animal. For an adult rat $80 \mathrm{ml} 0.9 \%$ saline should be infused over $3 \mathrm{~min}$. For a mouse $20 \mathrm{ml}$ saline should be infused over $2 \mathrm{~min}$. Progress of the perfusion may be monitored by assessment of the eyes and gums which should be blanched toward the end of this step.

9. Switch perfusion to $0.1 \mathrm{M}$ phosphate buffer $(\mathrm{PB})$ containing $4 \%$ paraformaldehyde. It is common to see turgor and twitching of the upper extremities at the initial flow of fixative into the animal. Perfuse an adult rat, $300 \mathrm{ml}$ of fixative over $10 \mathrm{~min}$ should be 
used. For a mouse approximately $80 \mathrm{ml}$ over $5 \mathrm{~min}$ of fixative should be infused. After completion of the procedure, the arms and tip of the nose should be stiff.

10. Disconnect the rat or mouse from the perfusion apparatus and carefully remove the organ to avoid damage to the tissue. After carefully removing organ from the body, continue fixation of adult tissue at room temperature for $3 \mathrm{~h}$.

11. Following incubation, tissue for IHC should be paraffin-embedded and then sectioned at $5 \mu \mathrm{m}$ thickness onto silanized glass slides. Slides may be stored at ambient temperature in slide cases until use.

\subsubsection{Detailed procedure for IHC staining}

Step A. Immunofluorescent staining procedure

1. Paraffin sections of human or animal tissues are deparaffinized in xylene for 3 min with frequent shaking in a glass box. Then, the sections are treated in xylene in another glass box for $3 \mathrm{~min}$, followed by the treatment with 100, 90, 80, 70, and 50\% (v/v) ethanol for 30-60 sec. To insure complete removal of paraffin, soak sections in PBS for $30 \mathrm{~min}$.

2. To retrieve the antigens, the sections are heated in $5 \%(\mathrm{w} / \mathrm{v})$ urea for $5 \mathrm{~min}$ in a microwave oven, and then left sections on the $5 \%$ urea until the temperature reducing to room temperature.

3. Rinse sections in PBS at room temperature, 3 times for 5 min each.

4. Block sections by $30 \mathrm{~min}$ incubation in PBS containing $5 \%(\mathrm{v} / \mathrm{v})$ normal goat serum antibody buffer, or $5 \%(\mathrm{w} / \mathrm{v})$ skim milk.

5. The sections are incubated with the primary antibody, rabbit polyclonal anti-8nitroguanine antibody $(1-2 \mu \mathrm{g} / \mathrm{ml})$, overnight at room temperature. When double immunofluorescence labeling study is performed, mouse monoclonal antibody is mixed with anti-8-nitroguanine antibody and the sections are treated with this mixture. Note: the final concentration of antibody depends on the specific antibody preparation being used and may need to be empirically determined.

6. The sections are washed with PBS at room temperature, 3 times for 5 min each.

7. The sections are incubated with the secondary antibody, Alexa 594-labeled goat antibody against rabbit IgG (1:400) for $3 \mathrm{~h}$ at room temperature. When double immunofluorescence labeling study is performed, Alexa 488-labeled goat antibody against mouse IgG (1:400) is mixed with Alexa 594-labeled goat antibody against rabbit IgG and the sections are treated with this mixture. Note: if primary serum is derived from a source other than rabbit, then the choice of secondary antibody should be adjusted accordingly for specificity.

8. Wash sections with PBS 3 times over $30 \mathrm{~min}$.

9. Pipet Dapi-Fluoromount-GTM Mounting Medium onto the section and then cover with a cover glass. Dry overnight covered at $4^{\circ} \mathrm{C}$ on a refrigerator.

10. The stained sections are examined under a fluorescent microscope.

Step B. Peroxidase anti-peroxidase immunohistochemical method

1. Deparaffinize as Step A (1)

2. To retrieve the antigens as Step A (2).

3. Rinse sections in PBS at room temperature, 3 times for 5 min each. 
4. The sections are incubated with $3 \% \mathrm{H}_{2} \mathrm{O}_{2}$ for $30 \mathrm{~min}$, and rinse sections in PBS for 10 min at room temperature.

5. Block sections by 30 min incubation in PBS containing $5 \%(v / v)$ normal goat serum or $5 \%(\mathrm{w} / \mathrm{v})$ skim milk.

6. The sections are incubated with the primary antibody, rabbit polyclonal anti-8nitroguanine antibody $(1-2 \mu \mathrm{g} / \mathrm{ml})$, overnight at room temperature.

7. Wash sections in PBS at room temperature, 3 times for 5 min each.

8. The sections are incubated with goat anti-rabbit IgG antibody (1:200) for $3 \mathrm{~h}$ at room temperature, fellow by wash in PBS, 3 times for 5 min each.

9. The sections are incubated with peroxidase anti-peroxidase complex (PAP, 1:200) for $2 \mathrm{~h}$ at room temperature, fellow by wash in PBS, 3 times for 5 min each.

10. Equilibrate sections in $0.05 \mathrm{M}$ Tris, $\mathrm{pH} 7.5$ with two washes for $10 \mathrm{~min}$ each.

11. Incubate sections in DAB/Tris solution $10 \mathrm{mg} \mathrm{3,3-diaminobenzidine} \mathrm{tetrahydrochloride}$ dihydrate in $100 \mathrm{ml} 0.05 \mathrm{M}$ Tris, $\mathrm{pH}$ 7.4; filter under a hood with general usage filter paper. Incubate sections in developer for up to $15 \mathrm{~min}$. Check sections frequently under a microscope for the degree of development, and reaction product is brown.

12. Terminate reaction by washing sections 3 times for 10 min each in $0.05 \mathrm{M}$ Tris, $\mathrm{pH}$ 7.4.

13. Wash sections 2 times for $5 \mathrm{~min}$ in distilled water (DW).

14. Counterstain sections with Mayer hematoxylin for 1-1.5 min if necessary.

15. Wash sections 2 times for 5 min in DW.

16. Dehydrate sections in Coplin jars containing graded ethanol 50-80\%, 3 min each; twice in $95 \%$ ethanol 3 min each; and 3 times in $100 \%$ ethanol 3 min each. Tissue is cleared by incubation 3 times for 5 min each in xylene, and coverslipped using Maninol mounting medium.

\section{Step C. Pre-absorption immunostaining}

To prepare pre-absorbed 8-nitroguanine antibody place equal amounts of 8-nitroguanine antibody in $1.5 \mathrm{ml}$ Eppendorf microfuge tubes. For the primary antibody to be pre-absorbed pure 8-nitroguanine is added to give a final protein concentration greater than $1 \mu \mathrm{g} / \mathrm{ml}$. An equal amount of diluents without 8-nitroguanine is added to the control antiserum. Mixtures are incubated for $2 \mathrm{~h}$ at room temperature and then diluted to their final working concentration with antibody buffer. Pre-absorption is then continued by incubation overnight at $4^{\circ} \mathrm{C}$ prior to use. Control and pre-absorbed antibody are used in parallel at StepA or StepB. Proceed as StepA (1) through (10).

\section{8-Nitroguanine accumulation in inflammation-related cancer}

\subsection{Application of Immunochemistry employing anti-8-nitroguanine antibody}

We have performed immunohistochemical analysis for 8-nitroguanine formation in various clinical specimens and animal models of inflammation-related carcinogenesis. We have firstly demonstrated that 8-nitroguanine is formed at the sites of carcinogenesis regardless of etiology, and we have proposed the possibility that 8-nitroguanine is a potential biomarker to evaluate the risk of inflammation-associated carcinogenesis (Kawanishi \& Hiraku, 2006; Kawanishi et al., 2006). In clinical specimens, 8-nitroguanine was formed in the gastric grand epithelial cells of patients with gastritis caused by Helicobacter pylori (H. pylori) 
infection (Ma et al., 2004), hepatocytes of patients with chronic hepatitis C (Horiike et al., 2005), oral precancerous lesions oral lichen planus (OLP) (Chaiyarit et al., 2005) and oral leukoplakia (Ma et al., 2006), soft tissue sarcoma (Hoki et al., 2007a; Hoki et al., 2007b) and Epstein-Barr virus (EBV)-associated nasopharyngeal carcinoma (NPC) (Ma et al., 2008).

In animal models, 8-nitroguanine was formed in a mouse model of inflammatory bowel disease (IBD) (Ding et al., 2005). 8-Nitroguanine was formed in the bile duct epithelium of the liver of hamsters infected with the liver fluke, Opisthorchis viverrini, which causes cancer of intrahepatic bile duct (Pinlaor et al., 2003; Pinlaor et al., 2004a). The treatment with praziquantel, an antiparasitic drug, reduced 8-nitroguanine formation (Pinlaor et al., 2006).

\subsubsection{H.pylori gastritis and eradication treatment}

H. pylori infection, which is the major cause of atrophic gastritis, is a high risk factor for gastric carcinoma (Peek \& Blaser, 2002). Lipopolysacharide (LPS), a component of Gramnegative bacteria such as $H$. pylori, is a TLR4 ligand that induces inflammatory responses via NF- $\kappa B$ expression (Maeda S. et al., 2001). NF- $\kappa B$, which is involved in the regulation of iNOS, had been reported to function as a tumor promoter in inflammation-associated cancer (Surh et al., 2001; Pikarsky et al., 2004). In patients with H.pyroli-induced gastritis or gastric ulcers, iNOS is expressed in the infiltrating inflammatory cells (Mannick et al., 1996). ROS and RNS generated by inflammatory cells may contribute to carcinogenesis through the formation of DNA base lesions, such as 8-oxodG, which can lead to a G:C-to-T:A transversion (Shibutani et al., 1991; Kawanishi \& Murata, 2006). 8-oxodG, a marker of oxidative DNA damage, is found at a significantly increased level in the gastric epithelium of H. pylori-infected patients (Baik et al., 1996; Pignatelli et al., 2001). Therefore, in addition to 8-oxodG formation, the accumulation of 8-nitroguanine may play a key role in the initiation and/or promotion of inflammation-mediated carcinogenesis. To evaluate whether nitrative DNA damage plays a role early in the carcinogenic process triggered by $H$. pylori and the affection of $\mathrm{H}$. pylori eradication treatment on 8-nitroguanine formation, we used a double-immunofluorescence staining procedure to compare the formation of both 8nitroguanine and 8-oxodG in the gastric epithelium of gastritis patients with and without $H$. pylori infection, and before and after $H$. pylori eradication treatment patients.

The formation of 8-nitroguanine and 8-oxodG in gastric epithelium in gastritis patients with H. pylori infection is shown in Fig. 3. Notably, intense immunoreactivity of both lesions was observed to co-localize in gastric gland epithelial cells in patients with $H$. pylori infection (Fig. 3, HP(+)). On the other hand, in gastritis patients without $H$. pylori infection, little or no immunoreactivity was observed in gastric gland epithelial cells (Fig. 3, HP(-)). 8Nitroguanine formation was observed in both the nuclei and the cytoplasm of the labeled epithelial cells, suggesting that it can form in both DNA and RNA. The 8-oxodG immunoreactivity was coincident with that of 8-nitroguanine within the nuclei of gastric gland cells and surface epithelial cells in $H$. pylori-infected patients (Fig. 3, merged labeling in yellow). Regardless of the $H$. pylori infection status, immunoreactivity of 8-nitroguanine and 8-oxodG was observed in inflammatory cells.

Moreover, we found that 8-nitroguanine formation in patients with H. pylori infection was dramatically decreased by eradication. After eradication, reduction of 8-nitroguanine and 8oxodG formation in the epithelia was observed in $58 \%$ and $53 \%$ patients, respectively (Fig. 
4A, B). Despite the complete eradication of $H$. pylori, reduced 8-nitroguanine and 8-oxodG production by infiltrating inflammatory cells were found only in $26 \%$ and $36 \%$ patients, respectively. Mean 8-nitroguanine and 8-oxodG immunoreactivities in inflammatory cells was not significantly decreased after the eradication treatment.

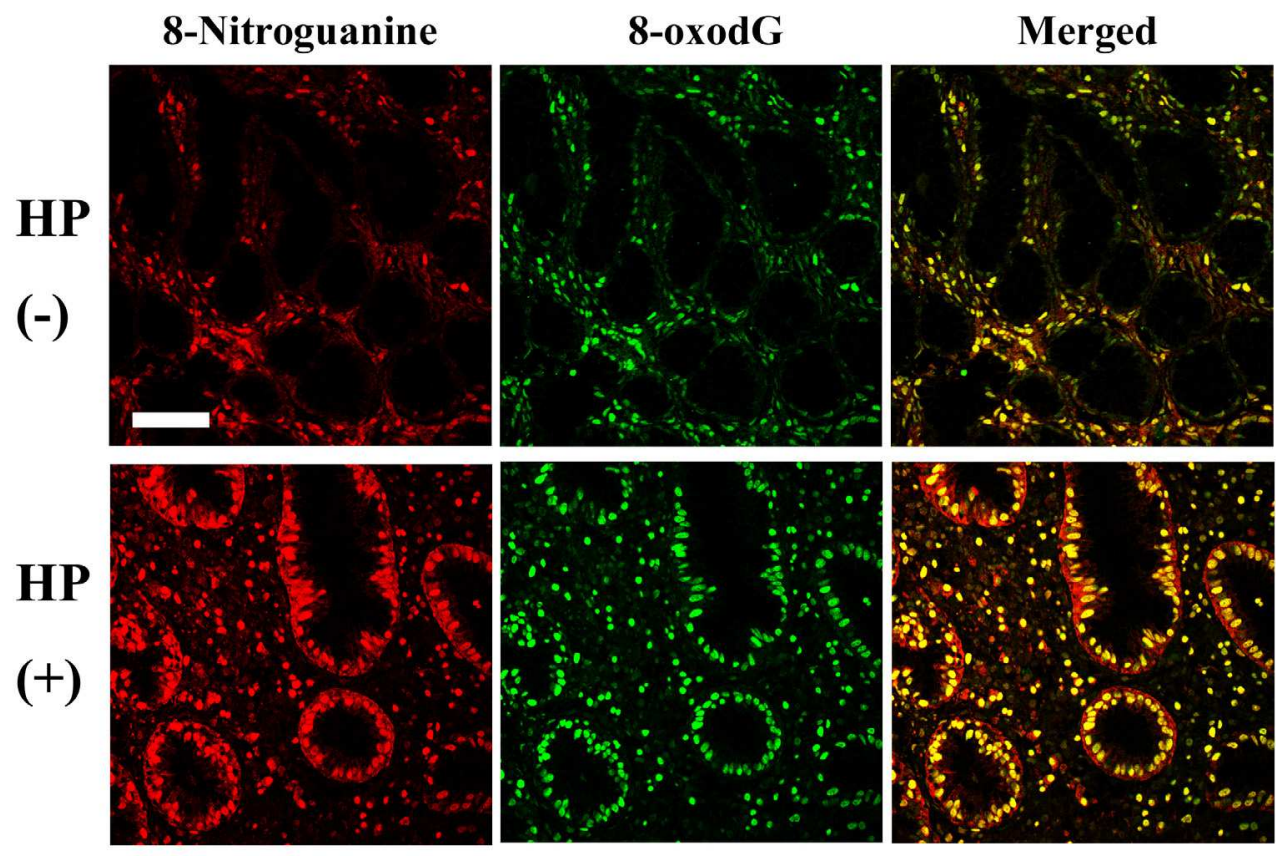

Fig. 3. 8-Nitroguanine and 8-oxodG formation in gastritis patients with and without $H$. pylori infection. Double immunofluorescence staining of paraffin sections shows the localization of 8-oxodG and 8-nitroguanine in the gastric epithelium. In H. pylori-infected patients $(\mathrm{HP}(+))$, the immunoreactivity of 8-nitroguanine and 8-oxodG co-localizes primarily in the nuclei of gastric gland epithelial cells and in some inflammatory cells in the corpus (Merged). In chronic gastritis patients without $H$. pylori-infection ( $\mathrm{HP}(-))$, the immunoreactivity of 8-nitroguanine and 8-oxodG is observed mainly in the inflammatory cells, while the gastric gland epithelial cells displayed little or no immunoreactivity. Scale bar represents $50 \mu \mathrm{m}$. 

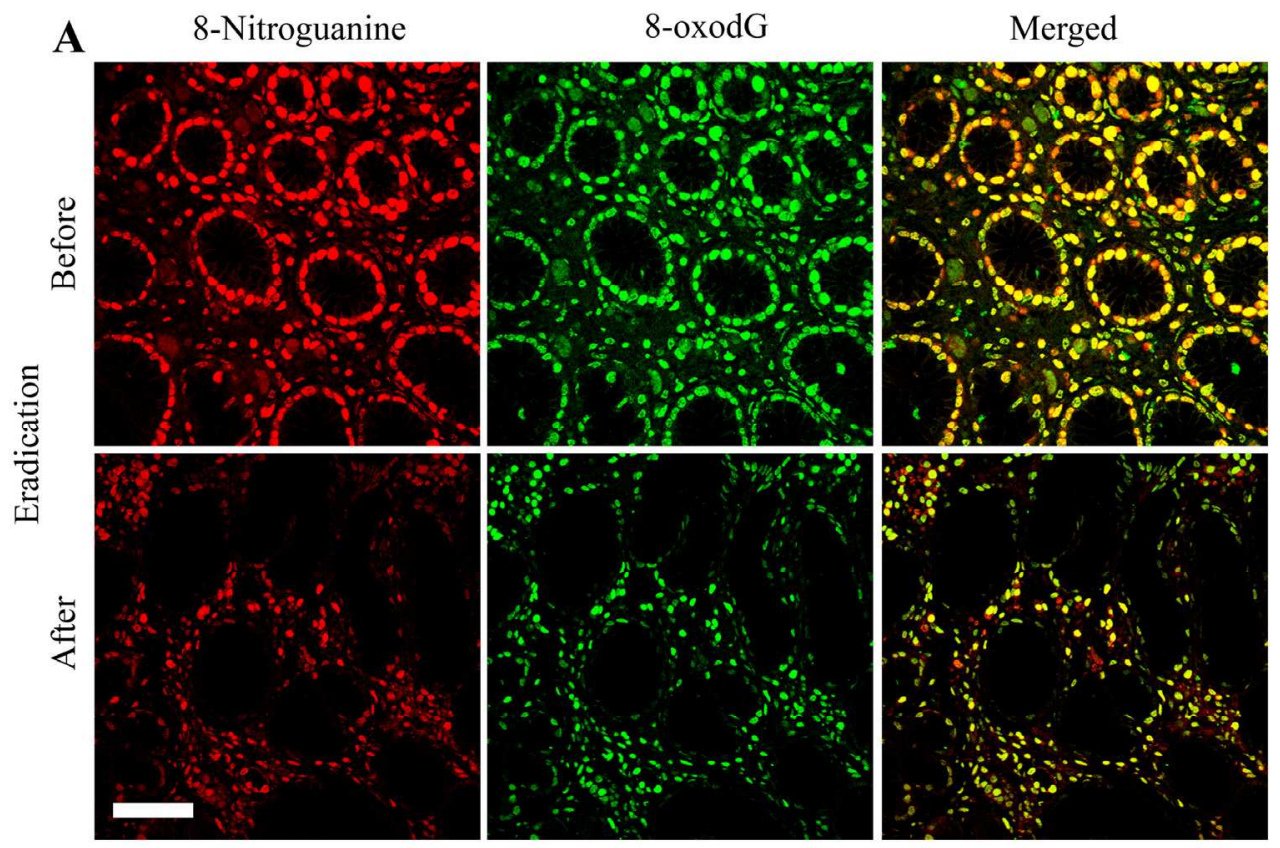

\section{B HP+ Before Eradication}

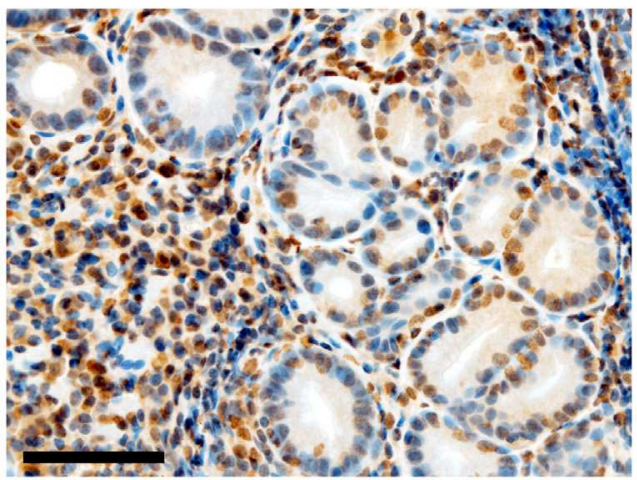

After Eradication

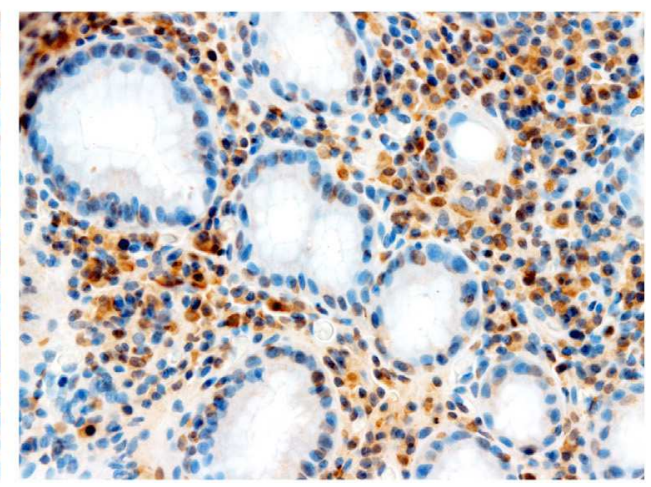

Fig. 4. Detective 8-nitroguanine and 8-oxodG formation in the H. pylori eradication patients by double immunofluorescent method (A) and peroxidase anti-peroxidase immunohistochemical method (B). Positive immunoreactivity for 8-nitroguanine was predominantly localized in the nuclei and cytosol of foveolar cells, neutrophils and lymphocytes. The immunoreactivity of 8-nitroguanine and 8-oxodG on the nuclei of foveolar cells was greater reduced after successful $H$. pylori eradication. Conversely, reduced 8-nitroguanine and 8-oxodG formation in infiltrating inflammatory cells did not significantly decrease after the treatment. Scale bar represents $50 \mu \mathrm{m}$. 
The mechanisms by which H. pylori infection causes gastric cancer have been investigated. LPS, a component of Gram-negative bacteria, including H. pylori, is a ligand of TLR4. TLR4 is involved in activation of the transcription factor NF-кB (Maeda H. \& Akaike, 1998), which mediates expression of iNOS and various inflammatory cytokines. Alternatively, the Cagpositive H.pylori strain induces an intense inflammatory response, including interleukin- 8 (IL-8) production by epithelial cells and subsequent production of tumor necrosis factor (TNF- $\alpha$ ) by inflammatory cells (Peek \& Blaser, 2002). The host immune response to H. pylori mediated by cytokines, resulting in iNOS expression, may lead to an increase in the accumulation of 8-nitroguanine and 8-oxodG in gastric epithelium.

\subsubsection{Leukoplakia, oral lichen planus and oral cancer}

More than 300,000 new cases are being diagnosed with oral squamous cell carcinoma annually in the world (Sudbo \& Reith, 2005). Oral leukoplakia is a precancerous lesion characterized by white plaque and hyperkeratosis (Neville \& Day, 2002; Reibel, 2003). Five to $15 \%$ of leukoplakia is histologically classified as dysplasia (Suarez et al., 1998; Sudbo \& Reith, 2005). The presence of epithelial dysplasia may be important in predicting malignant development. A substantial part of dysplasia is reported to develop into oral carcinoma (Lumerman et al., 1995; Sudbo \& Reith, 2005). Oral lichen planus (OLP) is a chronic inflammatory mucosal disease (Scully et al., 1998). Several pathological features indicate that OLP is an immunologically mediated inflammatory response, including an intense, band-like infiltrate of predominantly T-lymphocytes subjacent to epithelium. Basal epithelial cells are the target for immune destruction by cytotoxic T-lymphocytes (Tyldesley \& Appleton, 1973; Dekker et al., 1997). The most important complication of OLP is development of oral squamous cell carcinoma (OSCC) (Rajentheran et al., 1999; Mignogna et al., 2004).

Antioxidants have induced regression of precancerous oral lesions including leukoplakia (Enwonwu \& Meeks, 1995), suggesting that ROS are involved in the pathogenesis of precancerous lesions. ROS are considered to participate in carcinogenesis by forming oxidative DNA lesions, such as 8-oxodG (Kawanishi et al., 2001; Kawanishi et al., 2002).

A chronic inflammatory infiltration was generally present in oral tissues of leukoplakia patients (Rodriguez-Perez \& Banoczy, 1982). Expression of COX-2, an inflammatory mediator, was increased in oral mucosa with various lesions of leukoplakia, including hyperplasia and dysplasia (Renkonen et al., 2002; Altorki et al., 2004). These reports implicate that inflammation may mediate the development of oral cancer from leukoplakia. Therefore, we examined whether nitrative stress contributes to the development of oral carcinogenesis from leukoplakia through DNA damage.

We demonstrated that accumulation of 8-nitroguanine and 8-oxodG was observed in oral epithelium of biopsy specimens from patients with OLP and OSCC, whereas no immunoreactivity was observed in normal oral mucosa (Chaiyarit et al., 2005). 8Nitroguanine and 8-oxodG were also observed in oral epithelium of patients with leukoplakia (Ma et al., 2006). Co-localization of 8-nitroguanine and iNOS was found in oral epithelium of patients with OLP, OSCC and leukoplakia. Immunoreactivity of 3nitrotyrosine, which is formed by protein tyrosine nitration and considered to be a 
biochemical marker for inflammation, was also observed in oral epithelial cells. Accumulation of p53 was observed in oral epithelium in OLP and leukoplakia, and more prominent expression of this protein was observed in OSCC patients. Our findings demonstrate that iNOS-dependent DNA damage may lead to p53 accumulation not only in OLP and leukoplakia, but also in OSCC. It is concluded that the formation of 8-nitroguanine and 8-oxodG may contribute to the development of oral cancer from OLP and leukoplakia.

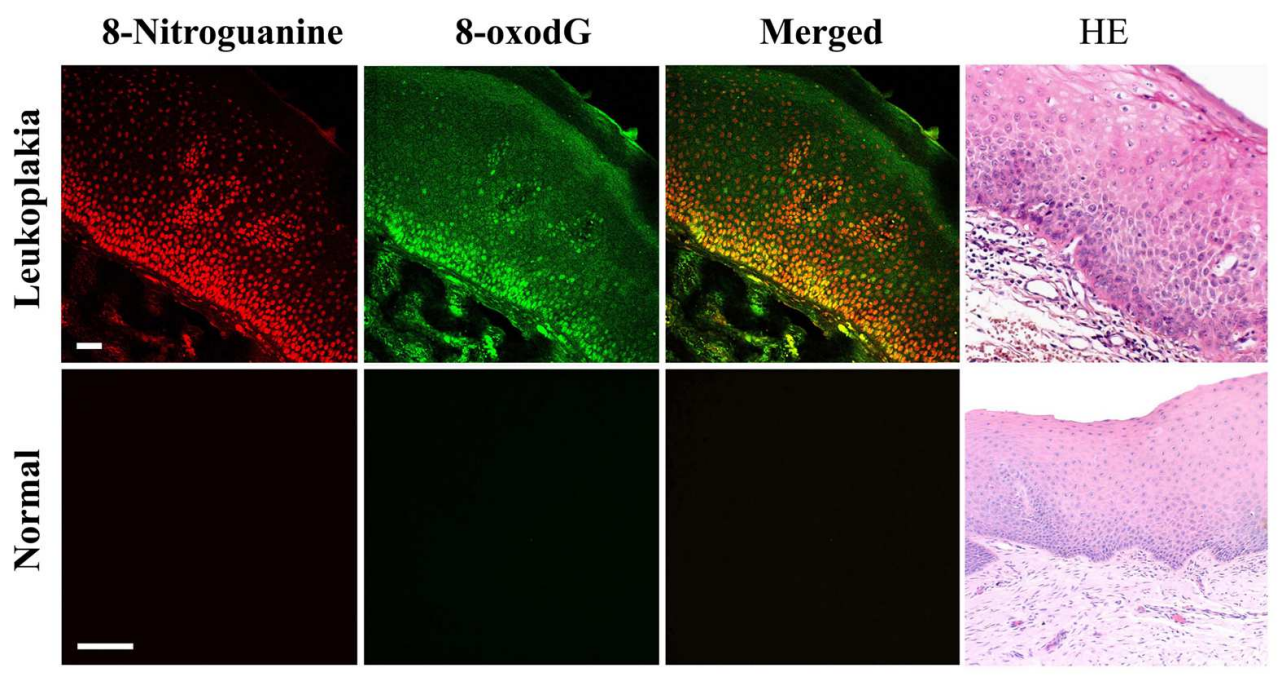

Fig. 5. Localization of 8-nitroguanine and 8-oxodG and histopathological changes in oral tissues of leukoplakia patients. Paraffin sections were immunostained with anti-8nitroguanine antibody and anti-8-oxodG antibody using double immunofluorescence technique as described in immunofluorescent staining procedure procedures. Strong 8nitroguanine and 8-oxodG immunoreactivities are observed in the nucleus of the same epithelial cells in supra-basal and basal layers and epithelial-connective tissue interface area of leukoplakia patients. The distribution of 8-nitroguanine- and 8-oxodG-positive cells is similar to that of dysplastic epithelial cells. Little or no immunoreactivity of 8-nitroguanine and 8-oxodG was observed in normal mucosa. Scale bar represents $50 \mu \mathrm{m}$. 


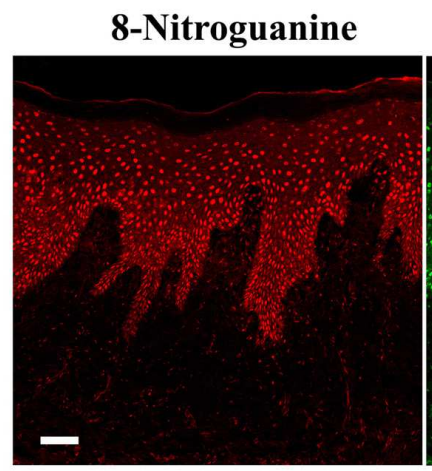

8-Nitroguanine

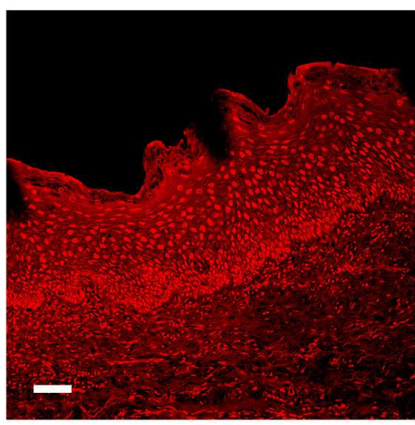

8-Nitroguanine

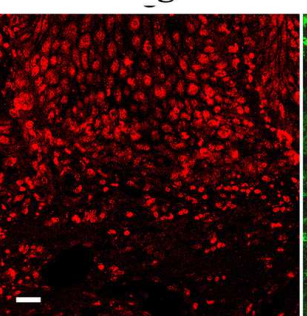

8-Nitroguanine

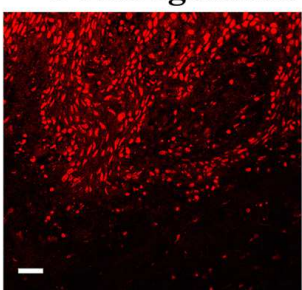

PCNA

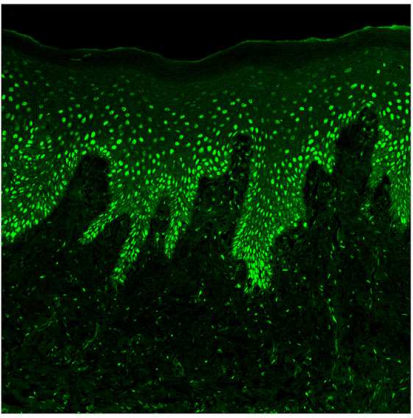

P53

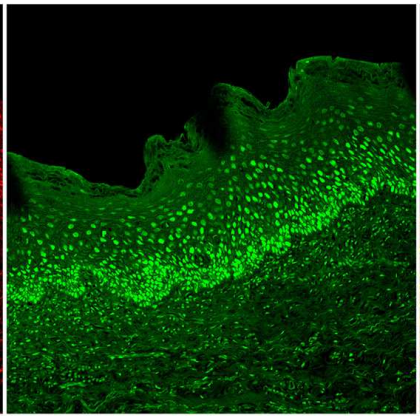

Merged

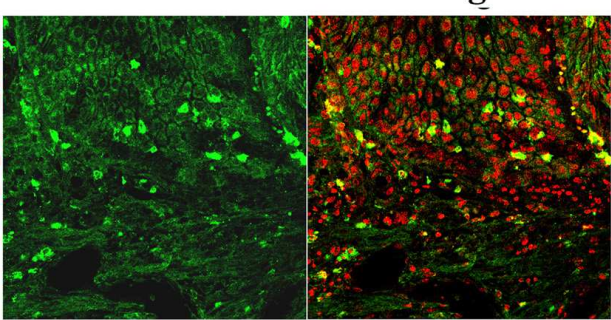

Merged
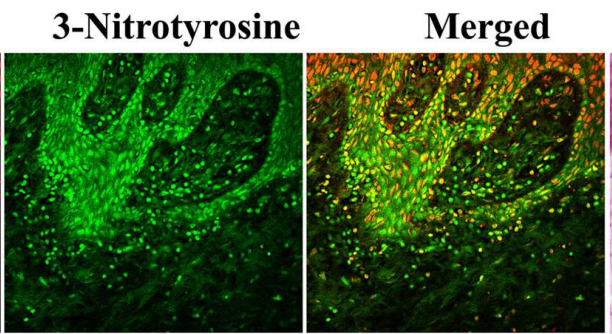

\section{Merged}

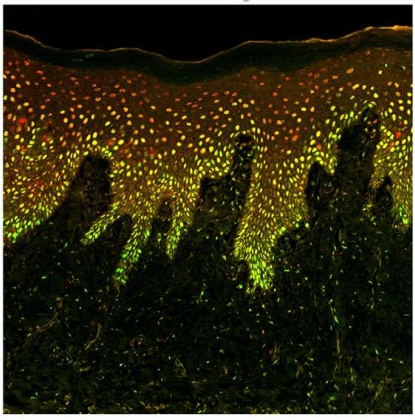

Merged

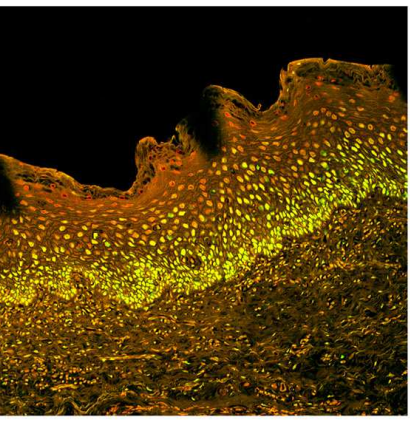

HE

HE

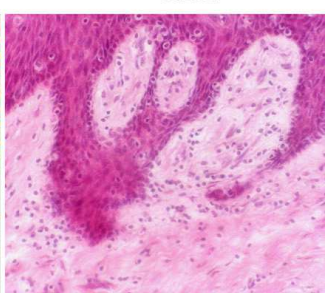

Fig. 6. Localization of 8-nitroguanine, PCNA, p53, iNOS and 3-nitrotyrosine in oral tissues of leukoplakia patients. Paraffin sections were immunostained with anti-8-nitroguanine 
antibody and anti-PCNA or anti-3-nitrotyrosine or anti-iNOS, p53 antibody using double immunofluorescence technique. 8-Nitroguanine formation is observed mainly in the nucleus of oral epithelial cells. Strong expression of PCNA and p53 was observed in the nucleus of 8nitroguanine-positive cells in the basal layer. iNOS expression is strongly observed in inflammatory cells and weakly in the cytoplasm of epithelial cells. Moreover, strong 8nitroguanine and 3-nitrotyrosine immunoreactivities are observed in the nucleus of the same epithelial cells. Scale bar represents $50 \mu \mathrm{m}$.

\subsubsection{Epstein-Barr virus and nasopharyngeal carcinoma}

NPC is a human epithelial tumor with a high prevalence in the southern Chinese population. In southern China, the incidence rate is about $25-50$ per 100,000 person-year and 100-fold higher than that in the Western world. In contrast to other head cancer and epithelial malignancy in general, a unique feature of NPC is its strong association with Epstein-Barr virus (EBV) (McDermott et al., 2001). Various transcription factors are known to participate in iNOS expression including signal transducers and activators of transcription (STATs), such as STAT1 $\alpha$ and STAT3 (Tedeschi et al., 2003; Lo et al., 2005). Epidermal growth factor receptor (EGFR) physically interacts with STAT3 in the nucleus, leading to transcriptional activation of iNOS (Lo et al., 2005). STAT3 is repeatedly activated through phosphorylation via the expression of latent membrane protein 1 (LMP1) as well as EGFR (Chen et al., 2003; Tao et al., 2005), and interleukin-6 (IL-6) is required for LMP1-mediated STAT3 activation (Chen et al., 2003). In addition, LMP1-mediated iNOS expression was reported in EBV-infected epithelium cell lines, which play a role in colonization independent of anchorage and tumorigenicity in nude mice ( $\mathrm{Yu}$ et al., 2002). We performed double immunofluorescent staining method to examine the formation of DNA lesions, 8-nitroguanine and 8-oxodG in surgical and biopsy specimens of nasopharyngeal tissues from NPC patients and chronic nasopharyngitis patients. We also examined the expression of iNOS, STAT3, EGFR and IL-6 in these specimens to examine contribution of these molecules to iNOS expression for 8-nitroguanine formation.

Using biopsy and surgical specimens of nasopharyngeal tissues from NPC patients in southern China, we performed double immunofluorescent staining to examine the formation of 8-nitroguanine and 8-oxodG (Ma et al., 2008; Huang et al., 2011). Intensive immunoreactivity of iNOS was detected in the cytoplasm of 8-nitroguanine-positive cancer cells. DNA lesions and iNOS expression were also observed in epithelial cells of EBV-positive patients with chronic nasopharyngitis but weaker than those in NPC patients (Fig. 7.). No or few DNA lesions were observed in EBV-negative subjects. EGFR and phosphorylated STAT3 were strongly expressed in cancer cells of NPC patients, suggesting that the STAT3-dependent mechanism is important to the carcinogenesis (Ma et al., 2008). IL-6 was expressed mainly in inflammatory cells of nasopharyngeal tissues of EBV-infected patients. We also found that serum levels of 8-oxodG were significantly higher in NPC patients than control subjects (Huang et al., 2011). Collectively, these findings indicate that the nuclear accumulation of EGFR and activation of STAT3 by IL-6 play a key role in iNOS expression and resultant DNA damage, leading to EBV-related NPC. 

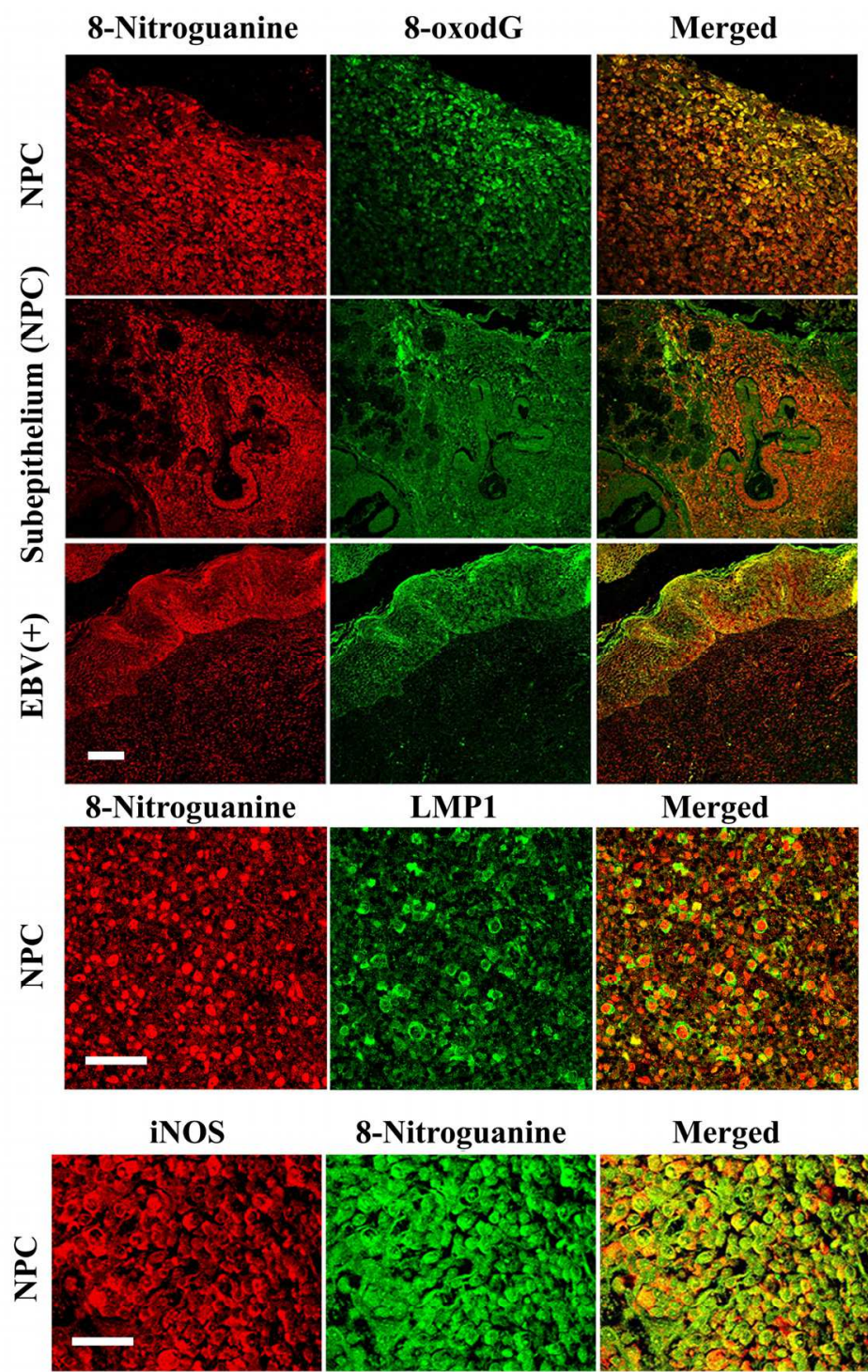

8-Nitroguanine

Merged

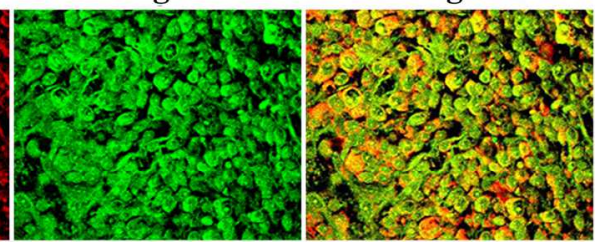

Stat3

EGFR
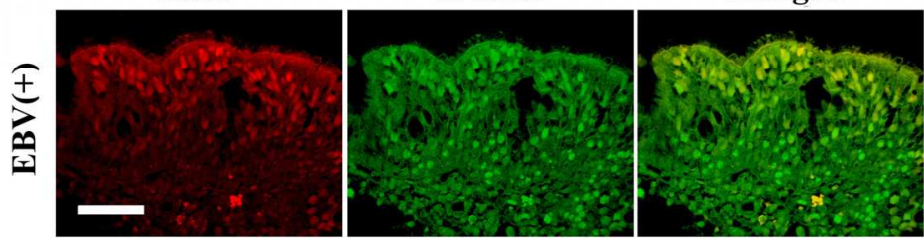

Fig. 7. Formation of 8-nitroguanine and 8-oxodG and expression of LMP, iNOS, STAT3 and EGFR in the nasopharyngeal tissues of NPC and chronic nasopharyngitis patients. 
8-Nitroguanine and 8-oxodG are co-localized in cancer cells. These DNA lesions are formed mainly in the nucleus and weakly in the cytoplasm. The formation of these DNA lesions was also observed in inflammatory cells in stroma in NPC patients and the epithelium in patients with chronic nasopharyngitis. Immunoreactivity of LMP1 is clearly observed along cell membrane and the cytoplasm of cancer cells. iNOS and 8-nitroguanine are colocalized in cancer cells of NPC patients. Expression of EGFR and STAT3 are colocalized in nasopharyngeal epithelical cells of EBV-positive chronic nasopharyngitis patients. Scale bar represents $50 \mu \mathrm{m}$.

\subsubsection{Inflammatory bowel diseases and colon cancer}

Ulcerative colitis and Crohn's disease are well known as chronic inflammatory diseases in the lower bowel, and share many clinical and pathological characteristics. These diseases are referred to as inflammatory bowel disease (IBD), which leads to long-term impairment of intestinal structure and function (Podolsky, 2002). A large number of immunological abnormalities have been noted in patients with IBD (Bouma \& Strober, 2003). It is well established that an increased cancer risk occurs in tissues undergoing chronic inflammation. Epidemiological studies have suggested that the incidence of colorectal cancer in IBD is greater than the expected incidence in the general population (Ekbom et al., 1990; Langholz et al., 1992; Choi \& Zelig, 1994; Pikarsky et al., 2004). The histological and molecular signatures suggest an inflammation-driven carcinogenesis process in IBD patients. To evaluate whether nitrative DNA damage plays a role in the carcinogenic process triggered by IBD, we prepared a mouse model of IBD induced by transfer of CD45RBigh $\mathrm{CD}^{+} \mathrm{T}$ cells lacking regulatory T cells to SCID mice (Powrie et al., 1993; Philippe et al., 2003), since mouse models of IBD can result from either excessive effector $\mathrm{T}$ cell function or deficient regulatory $\mathrm{T}$ cell function (Bouma \& Strober, 2003). We performed a double immunofluorescent staining procedure to examine the formation of 8-nitroguanine and 8oxodG in the colon tissues. We also examined the expression of iNOS by immunohistochemistry. To evaluate the proliferating activity of colonic epithelial cells and their response to DNA damage, we also examined the expression of p53 in the colon tissues.

In theCD45RB high CD4+Tcell-transferred mouse, significant 8-nitroguanine accumulation was induced in the nuclei and the cytoplasm of epithelial cells, and was also present in infiltrated cells supposed to be inflammatory cells in lamina propria. 8-Nitroguanine was formed in most of 8-oxodG-immunoreactive nuclei of epithelial cells and infiltrated cells (Fig. 8). When the sections were pretreated with RNase, 8-nitroguanine immunoreactivity was more clearly observed in the nuclei of epithelial cells (Ding et al., 2005). This result suggests that 8-nitroguanine was formed in genomic DNA. iNOS was expressed in the cytoplasm of epithelial cells and infiltrated cells in the lamina propria of the IBD mouse model (Fig. 8). iNOS was expressed mainly in 8-nitroguanine immunoreactive epithelial cells (Fig. 8). However, no or little 8-nitroguanine, 8-oxodG and iNOS were observed in nontreated control mice. In the IBD mouse model, significant p53 was accumulated in the nuclei of regenerated epithelial cells. P53 was also expressed in some infiltrated cells. P53 expression was overlapped with 8-nitroguanine (Fig. 8). The mice of IBD model that we used by transfer of $\mathrm{CD}_{45 \mathrm{RB}}{ }^{\text {high }} \mathrm{CD} 4^{+} \mathrm{T}$ cells showed the similar results of histopathological analysis and immunohistochemical staining. No or little expression of p53 was observed in non-treated control mice. 
8-Nitroguanine

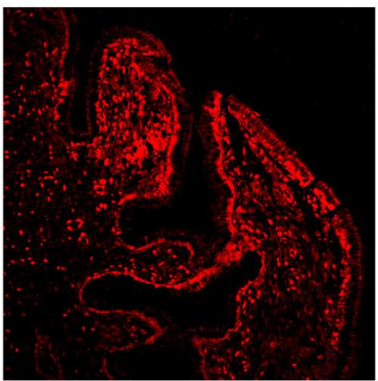

8-Nitroguanine

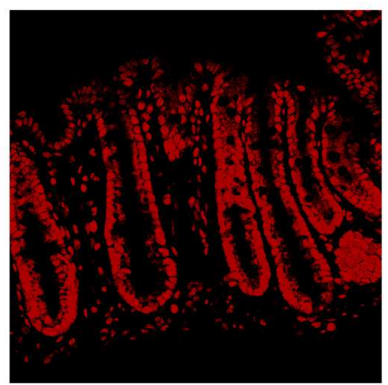

8-Nitroguanine

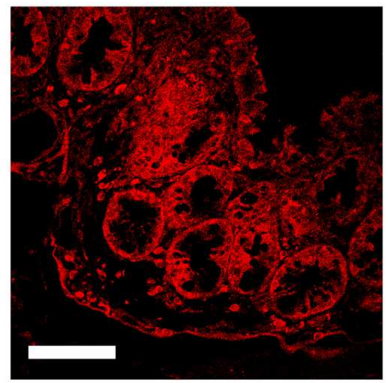

\section{8-oxodG}

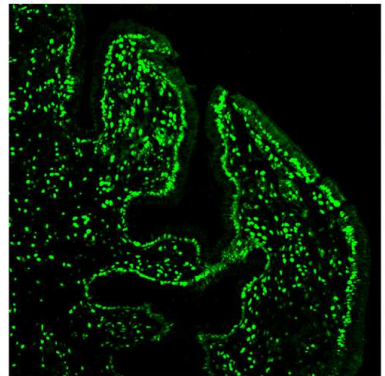

iNOS

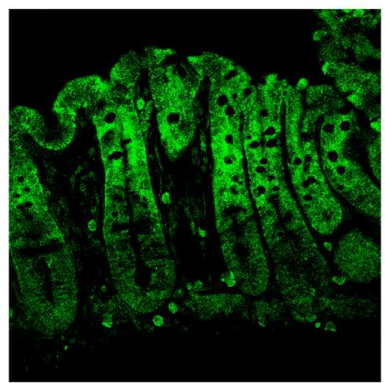

P53

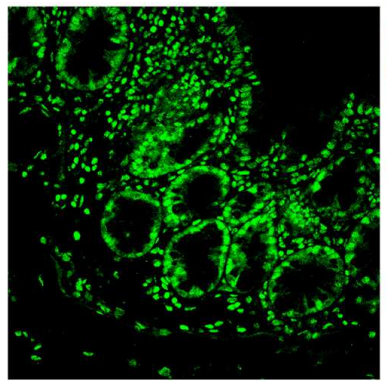

Merged

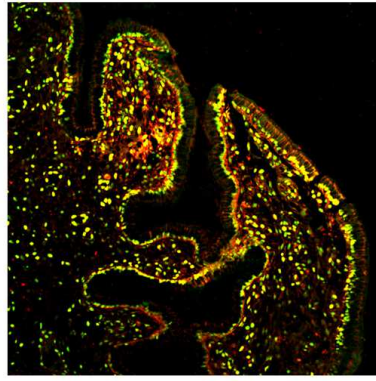

Merged

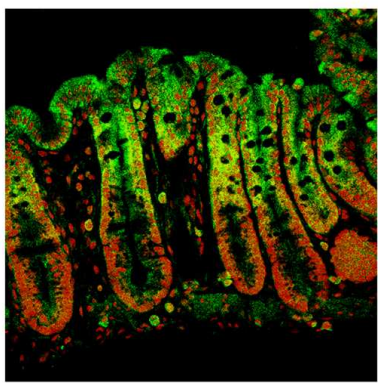

Merged

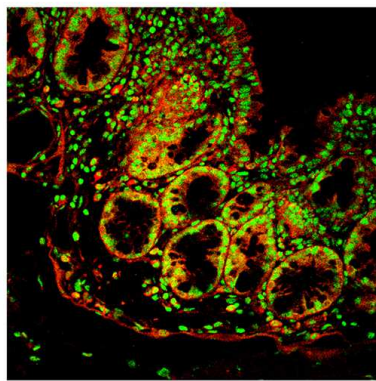

Fig. 8. Formation of 8-nitroguanine, 8-oxodG, iNOS and p53 in the mouse model of inflammatory bowel disease. 8-Nitroguanine is accumulated in the nuclei and the cytoplasm of epithelial cells. 8-Nitroguanine is also present in infiltrated cells. 8-oxodG formation is observed in the nuclei of epithelial cells and the infiltrated cells in lamina propria, 8-oxodG and 8-nitroguanine co-localized in the nuclei of most epithelial cells and infiltrated cells, iNOS is expressed in the cytoplasm of epithelial cells and infiltrated cells in lamina propria, and iNOS and 8-nitroguanine colocalized in the cytoplasm of many epithelial cells and some infiltrated cells. Double immunostaining for 8-nitroguanine and p53, significant p53 expression is observed in the nuclei of regenerated epithelial cells and some infiltrated cells. P53 is also induced in the cytoplasm of many epithelial cells in lower portions of the gland. P53 is expressed in most of 8-nitroguanine-immunoreactive epithelial cells. Scale bar represents $50 \mu \mathrm{m}$. 


\section{Concluding}

We have investigated the mechanisms of oxidative and nitrative DNA damage induced by various inflammatory conditions. In relation to inflammation-related carcinogenesis, we examined the formation of 8-nitroguanine and 8-oxodG in human samples and animals. It is noteworthy that DNA damage was specifically induced at sites of carcinogenesis under various inflammatory conditions. In human samples, 8-nitroguanine formation was observed in gastric gland epithelial cells of patients with H. pylori infection (Ma et al., 2004) and in hepatocytes of patients with chronic hepatitis C (Horiike et al., 2005). 8-Nitroguanine was also formed in oral epithelium of OLP and OSCC patients (Chaiyarit et al., 2005; Ma et al., 2006). Moreover, in hamsters infected with the liver fluke Opisthorchis viverrini causing cholangiocarcinoma, 8-nitroguanine formation was induced in bile duct epithelium (Pinlaor et al., 2004b). 8-Nitroguanine formation was also found in colonic gland epithelial cells of mouse model of IBD (Ding et al., 2005). Therefore, 8-nitroguanine could be used as a potential biomarker to evaluate the risk of inflammation-related carcinogenesis. Recently, 8nitroguanosine has been reported to be a highly redox-active molecule that strongly stimulates $\mathrm{O}_{2} \bullet$-generation from NADPH-dependent reductases (Sawa et al., 2003). 8Nitroguaninemay be a cofactor for redox reaction and cell signaling implicated in diverse physiological and pathological events (Zaki et al., 2005). More importantly, experimental evidence has suggested that 8-nitroguanine is a mutagenic DNA lesion, which preferentially leads to G:C-to-T:A transversions (Yermilov et al., 1995b; Suzuki et al., 2005), in addition to 8-oxodG (Shibutani et al., 1991; Bruner et al., 2000). Indeed, G:C-to-T:A transversions have been observed in vivo in the ras gene (Bos, 1988) and the $p 53$ tumor suppressor gene in lung and liver cancer (Takahashi et al., 1989; Prahalad et al., 1999). We also investigated the role of DNA damage in carcinogenesis initiated by $\mathrm{K}$-ras mutation, using conditional transgenic mice. Immunohistochemical analysis revealed that mutagenic 8-nitroguanine and 8-oxodG were apparently formed in adenocarcinoma caused by mutated $\mathrm{K}$-ras. 8-Nitroguanine was co-localized with iNOS, NF-кB, IKK, MAPK, MEK, and mutated K-ras, suggesting that oncogenic $K$-ras causes additional DNA damage via signaling pathway involving these molecules. It is noteworthy that $\mathrm{K}$-ras mutation mediates not only cell over-proliferation but also the accumulation of mutagenic DNA lesions, leading to carcinogenesis (Ohnishi et al., 2011). These findings imply that DNA damage mediated by ROS and RNS may participate in carcinogenesis via activation of protooncogenes and inactivation of tumor suppressor genes. In conclusion, oxidative and nitrative DNA damage could be promising biomarkers to evaluate the risk of carcinogenesis induced by a wide variety of chemicals and inflammatory conditions.

\section{Acknowledgments and funding}

This work was supported by a Grant-in-Aid from the Ministry of Education, Culture, Sports, Science and Technology of Japan and Otsuka Pharmaceutical Co., Ltd. Japan.

\section{References}

Aggarwal, B. B. and Sung B. (2011). The relationship between inflammation and cancer is analogous to that between fuel and fire. Oncology (Williston Park), Vol.25, No.5 (Apr 30), pp. (414-418), 0890-9091 (Print) 
Akaike, T., Okamoto S., Sawa T., Yoshitake J., Tamura F., Ichimori K., Miyazaki K., Sasamoto K. and Maeda H. (2003). 8-Nitroguanosine formation in viral pneumonia and its implication for pathogenesis. Proc Natl Acad Sci U S A, Vol.100, No.2 (Jan 21), pp. (685-690), 0027-8424 (Print)

Altorki, N. K., Subbaramaiah K. and Dannenberg A. J. (2004). COX-2 inhibition in upper aerodigestive tract tumors. Semin Oncol, Vol.31, No.2 Suppl 7 (Apr), pp. (30-36), 0093-7754 (Print)

Baik, S. C., Youn H. S., Chung M. H., Lee W. K., Cho M. J., Ko G. H., Park C. K., Kasai H. and Rhee K. H. (1996). Increased oxidative DNA damage in Helicobacter pyloriinfected human gastric mucosa. Cancer Res, Vol.56, No.6 (Mar 15), pp. (1279-1282), 0008-5472 (Print)

Balkwill, F. and Mantovani A. (2001). Inflammation and cancer: back to Virchow? Lancet, Vol.357, No.9255 (Feb 17), pp. (539-545).

Bos, J. L. (1988). Ras oncogenes in hematopoietic malignancies. Hematol Pathol, Vol.2, No.2 pp. (55-63), 0886-0238 (Print)

Bouma, G. and Strober W. (2003). The immunological and genetic basis of inflammatory bowel disease. Nat Rev Immunol, Vol.3, No.7 (Jul), pp. (521-533), 1474-1733 (Print)

Bruner, S. D., Norman D. P. and Verdine G. L. (2000). Structural basis for recognition and repair of the endogenous mutagen 8-oxoguanine in DNA. Nature, Vol.403, No.6772 (Feb 24), pp. (859-866), 0028-0836 (Print)

Chaiyarit, P., Ma N., Hiraku Y., Pinlaor S., Yongvanit P., Jintakanon D., Murata M., Oikawa S. and Kawanishi S. (2005). Nitrative and oxidative DNA damage in oral lichen planus in relation to human oral carcinogenesis. Cancer Sci, Vol.96, No.9 (Sep), pp. (553-559), 1347-9032 (Print)

Chen, H., Hutt-Fletcher L., Cao L. and Hayward S. D. (2003). A positive autoregulatory loop of LMP1 expression and STAT activation in epithelial cells latently infected with Epstein-Barr virus. J Virol, Vol.77, No.7 (Apr), pp. (4139-4148), 0022-538X (Print)

Choi, P. M. and Zelig M. P. (1994). Similarity of colorectal cancer in Crohn's disease and ulcerative colitis: implications for carcinogenesis and prevention. Gut, Vol.35, No.7 (Jul), pp. (950-954), 0017-5749 (Print)

Coussens, L. M. and Werb Z. (2002). Inflammation and cancer. Nature, Vol.420, No.6917 (Dec 19-26), pp. (860-867).

Dekker, N. P., Lozada-Nur F., Lagenaur L. A., MacPhail L. A., Bloom C. Y. and Regezi J. A. (1997). Apoptosis-associated markers in oral lichen planus. J Oral Pathol Med, Vol.26, No.4 (Apr), pp. (170-175), 0904-2512 (Print)

Ding, X., Hiraku Y., Ma N., Kato T., Saito K., Nagahama M., Semba R., Kuribayashi K. and Kawanishi S. (2005). Inducible nitric oxide synthase-dependent DNA damage in mouse model of inflammatory bowel disease. Cancer Sci, Vol.96, No.3 (Mar), pp. (157-163), 1347-9032 (Print)

Ekbom, A., Helmick C., Zack M. and Adami H. O. (1990). Increased risk of large-bowel cancer in Crohn's disease with colonic involvement. Lancet, Vol.336, No.8711 (Aug 11), pp. (357-359), 0140-6736 (Print)

Enwonwu, C. O. and Meeks V. I. (1995). Bionutrition and oral cancer in humans. Crit Rev Oral Biol Med, Vol.6, No.1 pp. (5-17), 1045-4411 (Print)

Fujita, N., Sugimoto R., Ma N., Tanaka H., Iwasa M., Kobayashi Y., Kawanishi S., Watanabe S., Kaito M. and Takei Y. (2008). Comparison of hepatic oxidative DNA damage in 
patients with chronic hepatitis B and C. J Viral Hepat, Vol.15, No.7 (Jul), pp. (498507), 1365-2893 (Electronic)

Hofseth, L. J., Khan M. A., Ambrose M., Nikolayeva O., Xu-Welliver M., Kartalou M., Hussain S. P., Roth R. B., Zhou X., Mechanic L. E., Zurer I., Rotter V., Samson L. D. and Harris C. C. (2003a). The adaptive imbalance in base excision-repair enzymes generates microsatellite instability in chronic inflammation. J Clin Invest, Vol.112, No.12 (Dec), pp. (1887-1894), 0021-9738 (Print)

Hofseth, L. J., Saito S., Hussain S. P., Espey M. G., Miranda K. M., Araki Y., Jhappan C., Higashimoto Y., He P., Linke S. P., Quezado M. M., Zurer I., Rotter V., Wink D. A., Appella E. and Harris C. C. (2003b). Nitric oxide-induced cellular stress and p53 activation in chronic inflammation. Proc Natl Acad Sci U S A, Vol.100, No.1 (Jan 7), pp. (143-148), 0027-8424 (Print)

Hoki, Y., Hiraku Y., Ma N., Murata M., Matsumine A., Nagahama M., Shintani K., Uchida A. and Kawanishi S. (2007a). iNOS-dependent DNA damage in patients with malignant fibrous histiocytoma in relation to prognosis. Cancer Sci, Vol.98, No.2 (Feb), pp. (163-168), 1347-9032 (Print)

Hoki, Y., Murata M., Hiraku Y., Ma N., Matsumine A., Uchida A. and Kawanishi S. (2007b). 8-Nitroguanine as a potential biomarker for progression of malignant fibrous histiocytoma, a model of inflammation-related cancer. Oncol Rep, Vol.18, No.5 (Nov), pp. (1165-1169), 1021-335X (Print)

Horiike, S., Kawanishi S., Kaito M., Ma N., Tanaka H., Fujita N., Iwasa M., Kobayashi Y., Hiraku Y., Oikawa S., Murata M., Wang J., Semba R., Watanabe S. and Adachi Y. (2005). Accumulation of 8-nitroguanine in the liver of patients with chronic hepatitis C. J Hepatol, Vol.43, No.3 (Sep), pp. (403-410), 0168-8278 (Print)

Huang, Y. J., Zhang B. B., Ma N., Murata M., Tang A. Z. and Huang G. W. (2011). Nitrative and oxidative DNA damage as potential survival biomarkers for nasopharyngeal carcinoma. Med Oncol, Vol.28, No.1 (Mar), pp. (377-384), 1559-131X (Electronic)

Hussain, S. P. and Harris C. C. (2007). Inflammation and cancer: an ancient link with novel potentials. Int. J. Cancer, Vol.121, No.11 (Dec 1), pp. (2373-2380),

Hussain, S. P., Hofseth L. J. and Harris C. C. (2003). Radical causes of cancer. Nat Rev Cancer, Vol.3, No.4 (Apr), pp. (276-285), 1474-175X (Print)

Kamp, D. W., Shacter E. and Weitzman S. A. (2011). Chronic inflammation and cancer: the role of the mitochondria. Oncology (Williston Park), Vol.25, No.5 (Apr 30), pp. (400410, 413), 0890-9091 (Print)

Kawanishi, S. and Hiraku Y. (2006). Oxidative and nitrative DNA damage as biomarker for carcinogenesis with special reference to inflammation. Antioxid Redox Signal, Vol.8, No.5-6 (May-Jun), pp. (1047-1058), 1523-0864 (Print)

Kawanishi, S., Hiraku Y., Murata M. and Oikawa S. (2002). The role of metals in site-specific DNA damage with reference to carcinogenesis. Free Radic Biol Med, Vol.32, No.9 (May 1), pp. (822-832), 0891-5849 (Print)

Kawanishi, S., Hiraku Y. and Oikawa S. (2001). Mechanism of guanine-specific DNA damage by oxidative stress and its role in carcinogenesis and aging. Mutat Res, Vol.488, No.1 (Mar), pp. (65-76), 0027-5107 (Print)

Kawanishi, S., Hiraku Y., Pinlaor S. and Ma N. (2006). Oxidative and nitrative DNA damage in animals and patients with inflammatory diseases in relation to inflammationrelated carcinogenesis. Biol Chem, Vol.387, No.4 (Apr), pp. (365-372), 1431-6730 (Print) 
Kawanishi, S. and Murata M. (2006). Mechanism of DNA damage induced by bromate differs from general types of oxidative stress. Toxicology, Vol.221, No.2-3 (Apr 17), pp. (172-178), 0300-483X (Print)

Langholz, E., Munkholm P., Davidsen M. and Binder V. (1992). Colorectal cancer risk and mortality in patients with ulcerative colitis. Gastroenterology, Vol.103, No.5 (Nov), pp. (1444-1451), 0016-5085 (Print)

Lo, H. W., Hsu S. C., Ali-Seyed M., Gunduz M., Xia W., Wei Y., Bartholomeusz G., Shih J. Y. and Hung M. C. (2005). Nuclear interaction of EGFR and STAT3 in the activation of the iNOS/NO pathway. Cancer Cell, Vol.7, No.6 (Jun), pp. (575-589), 1535-6108 (Print)

Loeb, L. A. and Preston B. D. (1986). Mutagenesis by apurinic/apyrimidinic sites. Annu Rev Genet, Vol.20, pp. (201-230), 0066-4197 (Print)

Lumerman, H., Freedman P. and Kerpel S. (1995). Oral epithelial dysplasia and the development of invasive squamous cell carcinoma. Oral Surg Oral Med Oral Pathol Oral Radiol Endod, Vol.79, No.3 (Mar), pp. (321-329), 1079-2104 (Print)

Ma, N., Adachi Y., Hiraku Y., Horiki N., Horiike S., Imoto I., Pinlaor S., Murata M., Semba R. and Kawanishi S. (2004). Accumulation of 8-nitroguanine in human gastric epithelium induced by Helicobacter pylori infection. Biochem Biophys Res Commun, Vol.319, No.2 (Jun 25), pp. (506-510), 0006-291X (Print)

Ma, N., Kawanishi M., Hiraku Y., Murata M., Huang G. W., Huang Y., Luo D. Z., Mo W. G., Fukui Y. and Kawanishi S. (2008). Reactive nitrogen species-dependent DNA damage in EBV-associated nasopharyngeal carcinoma: the relation to STAT3 activation and EGFR expression. Int J Cancer, Vol.122, No.11 (Jun 1), pp. (25172525), 1097-0215 (Electronic)

Ma, N., Sasaki T., Sakata-Haga H., Ohta K., Gao M., Kawanishi S. and Fukui Y. (2009). Protective effect of taurine against nitrosative stress in the stomach of rat with water immersion restraint stress. Adv Exp Med Biol, Vol.643, pp. (273-283), 00652598 (Print)

Ma, N., Sasoh M., Kawanishi S., Sugiura H. and Piao F. (2010). Protection effect of taurine on nitrosative stress in the mice brain with chronic exposure to arsenic. J Biomed Sci, Vol.17 Suppl 1, pp. (S7), 1423-0127 (Electronic)

Ma, N., Tagawa T., Hiraku Y., Murata M., Ding X. and Kawanishi S. (2006). 8-Nitroguanine formation in oral leukoplakia, a premalignant lesion. Nitric Oxide, Vol.14, No.2 (Mar), pp. (137-143), 1089-8603 (Print)

Ma, N., Thanan R., Kobayashi H., Hammam O., Wishahi M., Leithy T. E., Hiraku Y., Amro E. K., Oikawa S., Ohnishi S., Murata M. and Kawanishi S. (2011). Nitrative DNA damage and Oct3/4 expression in urinary bladder cancer with Schistosomahaematobium infection. Biochem Biophys Res Commun, (Sep 17), pp. 1090-2104 (Electronic)

Maeda, H. and Akaike T. (1998). Nitric oxide and oxygen radicals in infection, inflammation, and cancer. Biochemistry (Mosc), Vol.63, No.7 (Jul), pp. (854-865), 0006-2979 (Print)

Maeda, S., Akanuma M., Mitsuno Y., Hirata Y., Ogura K., Yoshida H., Shiratori Y. and Omata M. (2001). Distinct mechanism of Helicobacter pylori-mediated NF-kappa B activation between gastric cancer cells and monocytic cells. J Biol Chem, Vol.276, No.48 (Nov 30), pp. (44856-44864), 0021-9258 (Print)

Mannick, E. E., Bravo L. E., Zarama G., Realpe J. L., Zhang X. J., Ruiz B., Fontham E. T., Mera R., Miller M. J. and Correa P. (1996). Inducible nitric oxide synthase, 
nitrotyrosine, and apoptosis in Helicobacter pylori gastritis: effect of antibiotics and antioxidants. Cancer Res, Vol.56, No.14 (Jul 15), pp. (3238-3243), 0008-5472 (Print)

McDermott, A. L., Dutt S. N. and Watkinson J. C. (2001). The aetiology of nasopharyngeal carcinoma. Clin Otolaryngol Allied Sci, Vol.26, No.2 (Apr), pp. (82-92), 0307-7772 (Print)

Mignogna, M. D., Fedele S., Lo Russo L., Lo Muzio L. and Bucci E. (2004). Immune activation and chronic inflammation as the cause of malignancy in oral lichen planus: is there any evidence ? Oral Oncol, Vol.40, No.2 (Feb), pp. (120-130), 13688375 (Print)

Neville, B. W. and Day T. A. (2002). Oral cancer and precancerous lesions. CA Cancer J Clin, Vol.52, No.4 (Jul-Aug), pp. (195-215), 0007-9235 (Print)

Ohnishi, S., Saito H., Suzuki N., Ma N., Hiraku Y., Murata M. and Kawanishi S. (2011). Nitrative and oxidative DNA damage caused by K-ras mutation in mice. Biochem Biophys Res Commun, Vol.413, No.2 (Sep 23), pp. (236-240), 1090-2104 (Electronic)

Ohshima, H., Tatemichi M. and Sawa T. (2003). Chemical basis of inflammation-induced carcinogenesis. Arch Biochem Biophys, Vol.417, No.1 (Sep 1), pp. (3-11), 0003-9861 (Print) 0003-9861 (Linking)

Peek, R. M., Jr. and Blaser M. J. (2002). Helicobacter pylori and gastrointestinal tract adenocarcinomas. Nat Rev Cancer, Vol.2, No.1 (Jan), pp. (28-37), 1474-175X (Print)

Philippe, D., Dubuquoy L., Groux H., Brun V., Chuoi-Mariot M. T., Gaveriaux-Ruff C., Colombel J. F., Kieffer B. L. and Desreumaux P. (2003). Anti-inflammatory properties of the mu opioid receptor support its use in the treatment of colon inflammation. J Clin Invest, Vol.111, No.9 (May), pp. (1329-1338), 0021-9738 (Print)

Pignatelli, B., Bancel B., Plummer M., Toyokuni S., Patricot L. M. and Ohshima H. (2001). Helicobacter pylori eradication attenuates oxidative stress in human gastric mucosa. Am J Gastroenterol, Vol.96, No.6 (Jun), pp. (1758-1766), 0002-9270 (Print)

Pikarsky, E., Porat R. M., Stein I., Abramovitch R., Amit S., Kasem S., Gutkovich-Pyest E., Urieli-Shoval S., Galun E. and Ben-Neriah Y. (2004). NF-kappaB functions as a tumour promoter in inflammation-associated cancer. Nature, Vol.431, No.7007 (Sep 23), pp. (461-466), 1476-4687 (Electronic)

Pinlaor, S., Hiraku Y., Ma N., Yongvanit P., Semba R., Oikawa S., Murata M., Sripa B., Sithithaworn P. and Kawanishi S. (2004a). Mechanism of NO-mediated oxidative and nitrative DNA damage in hamsters infected with Opisthorchis viverrini: a model of inflammation-mediated carcinogenesis. Nitric Oxide, Vol.11, No.2 (Sep), pp. (175-183), 1089-8603 (Print)

Pinlaor, S., Hiraku Y., Yongvanit P., Tada-Oikawa S., Ma N., Pinlaor P., Sithithaworn P., Sripa B., Murata M., Oikawa S. and Kawanishi S. (2006). iNOS-dependent DNA damage via NF-kappaB expression in hamsters infected with Opisthorchis viverrini and its suppression by the antihelminthic drug praziquantel. Int J Cancer, Vol.119, No.5 (Sep 1), pp. (1067-1072), 0020-7136 (Print)

Pinlaor, S., Ma N., Hiraku Y., Yongvanit P., Semba R., Oikawa S., Murata M., Sripa B., Sithithaworn P. and Kawanishi S. (2004b). Repeated infection with Opisthorchis viverrini induces accumulation of 8-nitroguanine and 8-oxo-7,8-dihydro-2'deoxyguanine in the bile duct of hamsters via inducible nitric oxide synthase. Carcinogenesis, Vol.25, No.8 (Aug), pp. (1535-1542), 0143-3334 (Print)

Pinlaor, S., Yongvanit P., Hiraku Y., Ma N., Semba R., Oikawa S., Murata M., Sripa B., Sithithaworn P. and Kawanishi S. (2003). 8-Nitroguanine formation in the liver of 
hamsters infected with Opisthorchis viverrini. Biochem Biophys Res Commun, Vol.309, No.3 (Sep 26), pp. (567-571), 0006-291X (Print)

Podolsky, D. K. (2002). Inflammatory bowel disease. N Engl J Med, Vol.347, No.6 (Aug 8), pp. (417-429), 1533-4406 (Electronic)

Powrie, F., Leach M. W., Mauze S., Caddle L. B. and Coffman R. L. (1993). Phenotypically distinct subsets of CD4+ $\mathrm{T}$ cells induce or protect from chronic intestinal inflammation in C. B-17 scid mice. Int Immunol, Vol.5, No.11 (Nov), pp. (1461-1471), 0953-8178 (Print)

Prahalad, A. K., Manchester D. K., Hsu I. C., Inmon J. and Gallagher J. E. (1999). Human placental microsomal activation and DNA adduction by air pollutants. Bull Environ Contam Toxicol, Vol.62, No.1 (Jan), pp. (93-100), 0007-4861 (Print)

Rajentheran, R., McLean N. R., Kelly C. G., Reed M. F. and Nolan A. (1999). Malignant transformation of oral lichen planus. Eur J Surg Oncol, Vol.25, No.5 (Oct), pp. (520523), 0748-7983 (Print)

Reibel, J. (2003). Prognosis of oral pre-malignant lesions: significance of clinical, histopathological, and molecular biological characteristics. Crit Rev Oral Biol Med, Vol.14, No.1 pp. (47-62), 1544-1113 (Electronic)

Renkonen, J., Wolff H. and Paavonen T. (2002). Expression of cyclo-oxygenase-2 in human tongue carcinoma and its precursor lesions. Virchows Arch, Vol.440, No.6 (Jun), pp. (594-597), 0945-6317 (Print)

Rodriguez-Perez, I. and Banoczy J. (1982). Oral leukoplakia. A histopathological study. Acta Morphol Acad Sci Hung, Vol.30, No.3-4 pp. (289-298), 0001-6217 (Print)

Rook, G. A. and Dalgleish A. (2011). Infection, immunoregulation, and cancer. Immunol Rev, Vol.240, No.1 (Mar), pp. (141-159), 1600-065X (Electronic)

Sawa, T., Akaike T., Ichimori K., Akuta T., Kaneko K., Nakayama H., Stuehr D. J. and Maeda H. (2003). Superoxide generation mediated by 8-nitroguanosine, a highly redoxactive nucleic acid derivative. Biochem Biophys Res Commun, Vol.311, No.2 (Nov 14), pp. (300-306), 0006-291X (Print)

Schetter, A. J., Heegaard N. H. and Harris C. C. (2010). Inflammation and cancer: interweaving microRNA, free radical, cytokine and p53 pathways. Carcinogenesis, Vol.31, No.1 (Jan), pp. (37-49), 1460-2180 (Electronic)

Scully, C., Beyli M., Ferreiro M. C., Ficarra G., Gill Y., Griffiths M., Holmstrup P., Mutlu S., Porter S. and Wray D. (1998). Update on oral lichen planus: etiopathogenesis and management. Crit Rev Oral Biol Med, Vol.9, No.1 pp. (86-122), 1045-4411 (Print)

Shibutani, S., Takeshita M. and Grollman A. P. (1991). Insertion of specific bases during DNA synthesis past the oxidation-damaged base 8-oxodG. Nature, Vol.349, No.6308 (Jan 31), pp. (431-434), 0028-0836 (Print)

Suarez, P., Batsakis J. G. and el-Naggar A. K. (1998). Leukoplakia: still a gallimaufry or is progress being made?--A review. Adv Anat Pathol, Vol.5, No.3 (May), pp. (137-155), 1072-4109 (Print) 1072-4109 (Linking)

Sudbo, J. and Reith A. (2005). The evolution of predictive oncology and molecular-based therapy for oral cancer prevention. Int J Cancer, Vol.115, No.3 (Jun 20), pp. (339345), 0020-7136 (Print)

Surh, Y. J., Chun K. S., Cha H. H., Han S. S., Keum Y. S., Park K. K. and Lee S. S. (2001). Molecular mechanisms underlying chemopreventive activities of antiinflammatory phytochemicals: down-regulation of COX-2 and iNOS through 
suppression of NF-kappa B activation. Mutat Res, Vol.480-481, (Sep 1), pp. (243268), 0027-5107 (Print)

Suzuki, N., Yasui M., Geacintov N. E., Shafirovich V. and Shibutani S. (2005). Miscoding events during DNA synthesis past the nitration-damaged base 8-nitroguanine. Biochemistry, Vol.44, No.25 (Jun 28), pp. (9238-9245), 0006-2960 (Print)

Takahashi, T., Nau M. M., Chiba I., Birrer M. J., Rosenberg R. K., Vinocour M., Levitt M., Pass H., Gazdar A. F. and Minna J. D. (1989). p53: a frequent target for genetic abnormalities in lung cancer. Science, Vol.246, No.4929 (Oct 27), pp. (491-494), 00368075 (Print)

Tanaka, H., Fujita N., Sugimoto R., Urawa N., Horiike S., Kobayashi Y., Iwasa M., Ma N., Kawanishi S., Watanabe S., Kaito M. and Takei Y. (2008). Hepatic oxidative DNA damage is associated with increased risk for hepatocellular carcinoma in chronic hepatitis C. Br J Cancer, Vol.98, No.3 (Feb 12), pp. (580-586), 0007-0920 (Print)

Tao, Y., Song X., Deng X., Xie D., Lee L. M., Liu Y., Li W., Li L., Deng L., Wu Q., Gong J. and Cao Y. (2005). Nuclear accumulation of epidermal growth factor receptor and acceleration of G1/S stage by Epstein-Barr-encoded oncoprotein latent membrane protein 1. Exp Cell Res, Vol.303, No.2 (Feb 15), pp. (240-251), 0014-4827 (Print)

Tedeschi, E., Menegazzi M., Margotto D., Suzuki H., Forstermann U. and Kleinert H. (2003). Anti-inflammatory actions of St. John's wort: inhibition of human inducible nitricoxide synthase expression by down-regulating signal transducer and activator of transcription-1alpha (STAT-1alpha) activation. J Pharmacol Exp Ther, Vol.307, No.1 (Oct), pp. (254-261), 0022-3565 (Print)

Trinchieri, G. (2011). Inflammation in cancer: a therapeutic target? Oncology (Williston Park), Vol.25, No.5 (Apr 30), pp. (418-420), 0890-9091 (Print)

Tyldesley, W. R. and Appleton J. (1973). Observations on the ultrastructure of the epithelium in oral lichen planus. J Oral Pathol, Vol.2, No.1 pp. (46-57), 0300-9777 (Print)

Yermilov, V., Rubio J., Becchi M., Friesen M. D., Pignatelli B. and Ohshima H. (1995a). Formation of 8-nitroguanine by the reaction of guanine with peroxynitrite in vitro. Carcinogenesis, Vol.16, No.9 (Sep), pp. (2045-2050), 0143-3334 (Print)

Yermilov, V., Rubio J. and Ohshima H. (1995b). Formation of 8-nitroguanine in DNA treated with peroxynitrite in vitro and its rapid removal from DNA by depurination. FEBS Lett, Vol.376, No.3 (Dec 4), pp. (207-210), 0014-5793 (Print)

Yu, J. S., Tsai H. C., Wu C. C., Weng L. P., Li H. P., Chung P. J. and Chang Y. S. (2002). Induction of inducible nitric oxide synthase by Epstein-Barr virus B95-8-derived LMP1 in Balb/3T3 cells promotes stress-induced cell death and impairs LMP1mediated transformation. Oncogene, Vol.21, No.52 (Nov 14), pp. (8047-8061), 09509232 (Print)

Zaki, M. H., Akuta T. and Akaike T. (2005). Nitric oxide-induced nitrative stress involved in microbial pathogenesis. J Pharmacol Sci, Vol.98, No.2 (Jun), pp. (117-129), 1347-8613 (Print) 


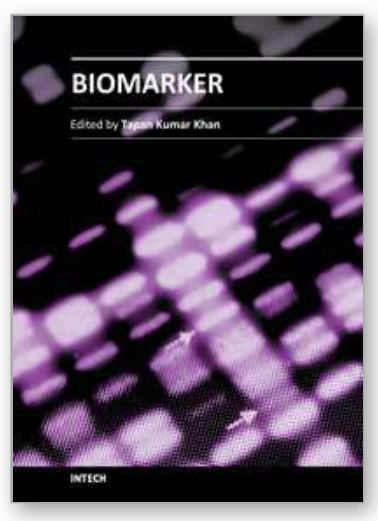

\author{
Biomarker \\ Edited by Prof. Tapan Khan
}

ISBN 978-953-51-0577-0

Hard cover, 392 pages

Publisher InTech

Published online 27, April, 2012

Published in print edition April, 2012

Clinicians, scientists, and health care professionals use biomarkers or biological markers as a measure of a person's present health condition or response to interventions. An ideal -biomarker should have the following criteria: (I) ability to detect fundamental features of the disease, (II) ability to differentiate from other closely related diseases, (III) ability to detect early stages and stages of progression, (IV) the method should be highly reliable, easy to perform and inexpensive, and (V) sample sources should be easily accessible from body. Most of the chapters in this book follow the basic principle of biomarkers.

\title{
How to reference
}

In order to correctly reference this scholarly work, feel free to copy and paste the following:

Ning Ma, Mariko Murata, Shiho Ohnishi, Raynoo Thanan, Yusuke Hiraku and Shosuke Kawanishi (2012). 8Nitroguanine, a Potential Biomarker to Evaluate the Risk of Inflammation-Related Carcinogenesis, Biomarker, Prof. Tapan Khan (Ed.), ISBN: 978-953-51-0577-0, InTech, Available from:

http://www.intechopen.com/books/biomarker/8-nitroguanine-a-potential-biomarker-to-evaluate-the-risk-ofinflammation-related-carcinogenesis

\section{INTECH}

open science | open minds

\section{InTech Europe}

University Campus STeP Ri

Slavka Krautzeka 83/A

51000 Rijeka, Croatia

Phone: +385 (51) 770447

Fax: +385 (51) 686166

www.intechopen.com

\section{InTech China}

Unit 405, Office Block, Hotel Equatorial Shanghai

No.65, Yan An Road (West), Shanghai, 200040, China

中国上海市延安西路65号上海国际贵都大饭店办公楼405单元

Phone: +86-21-62489820

Fax: $+86-21-62489821$ 
(C) 2012 The Author(s). Licensee IntechOpen. This is an open access article distributed under the terms of the Creative Commons Attribution 3.0 License, which permits unrestricted use, distribution, and reproduction in any medium, provided the original work is properly cited. 